\title{
XFELの概要とSACLAの特徵
}

理化学研究所放射光科学総合研究センター 矢橋牧名

\section{Makina YABASHI: Overview of XFEL and SACLA}

An overview of XFEL and SACLA is presented. Typical experimental methods for XFEL sources are introduced. Following a historical review, unique features of SACLA and future perspectives are summarized.

\section{1. はじめに}

X線自由電子レーザー（X-ray Free Electron Laser： XFEL)は, 今世紀になって実用化された新しいX線光 源である。米国LCLS (Linac Coherent Light Source) に 続き, 2012年には, 日本のXFEL施設 SACLA（SPring-8 Angstrom Compact free-electron LAser $)^{1), 2)}$ がユーザー ファシリティとしての運用を開始し, 本特集号で紹介さ れるように目覚ましい利用成果が報告されるようになっ た。一連の急激な発展は, 近年の光科学技術史のうえで も特筆すべき成果と言えよう。

XFELは非常にユニークな特徵をもつが，とりわけ従 来のX線光源との顕著な違いの 1 つは, そのパルス性に ある.XFEL光源は, 増幅作用により, 単一パルス内に膨 大な X線光子を生成する。しかも, パルス幅はフェムト 秒オーダーと極端に短く, 高い空間コヒーレンスも有す る。このような超高輝度XFELパルスは, X線管や放射 光といった従来の $\mathrm{CW}$ 的 (もしくは擬 $\mathrm{CW}$ 的) な $\mathrm{X}$ 線光 源とはまったく異なる実験デザインを可能とし, 新しい サイエンスの開拓を率引している。

拙稿では，本号中の各記事の紹介を兼ねながら， XFELの概要とSACLAの特徵について簡潔にまとめて みたい. 2 章では, XFELの典型的な使い方について紹介 する. 3 章では, XFELの歴史と SACLAのあゆみを概観 する. SACLAのユニークな特徵を紹介した後, 今後の 展望を述べる。

\section{2. どのように使うのか}

XFELのユニークな光特性を十二分に活用するために, 使う側に㧍いても新たな概念の導入と手法の開発が行わ れてきた。ここでは，その典型例を紹介したい。最も基本 的な概念の $1 つ か ゙, 「$ diffraction-before-destruction（破壊前 の回折計測)」である. ${ }^{3), 4)}$ 強度の高いXFELを試料に照射 すると, 激しい電離過程を経て試料内の原子は変位し, ついにはクーロン爆発によって試料は破壊されてしまう。
しかし, XFELのフェムト秒のパルス幅は, 照射後に原子 が動き始める時間 (サブピコ秒からピコ秒のオーダー) よ り十分短いため, 試料の分子構造が変化する前のオリジ ナルの情報を, 回折・散乱・分光などのX線分析手法に よって取得することが可能となる。例えば, 生体高分子 の結晶構造解析に扔いて, 放射光を含む従来の CW光源 では, 長時間のX線照射が引き起こす試料の化学的な損 傷が問題となっていた、これを抑制するために，試料を 低温に冷却するという方法が適用されてきたが，損傷の 影響を完全に回避することは不可能であった，これに対 し, 岡山大学の沈建仁教授らは, SACLAを利用して, 光 合成の鍵を握る光化学系タンパク質の無損傷の分子構造 を決定することに成功した.5)また，XFELによって，試料 が抢かれた環境（温度・湿度・pHなど）を自在に制御し ながら精密構造解析を行うことも可能となった. さらに, 入射 X線の光子密度を高めていくことにより, ナノ結晶, 二次元結晶や単粒子といった微小な試料に対しても, $\mathrm{CW}$ 光源の限界を超えた空間分解能を達成することができる. 生きた細胞のコヒーレント回折イメージング6)について, 西野吉則氏らの記事を参照されたい

また，XFELの極短パルス特性を活かすと，フェムト 秒の時間分解能で分子構造や電子状態の変化を追いか ける,いわゆる「molecular movie (分子動画)」の撮影が 可能となる.4) 具体的には, 系に刺激 (ポンプ)を与え, 一 定の時間間隔（ディレイ）を扔いてXFELによって状態 をプローブするという, ポンプ・プローブ法が用いられ る。この技法は, すでにフェムト秒光学レーザーの利用 研究に打いて広く用いられてきたが, ポンプとして光学 レーザー, プローブとしてXFELパルスを用いることによ り，オングストロームの空間分解能とフェムト秒の時間 分解能の両立が初めて実現された，光がトリガーになっ て引き起こす超高速の化学反応や物性変化の起源に迫 ることができると期待されている. 本特集号には, 膜夕 ンパク質,7) 光触媒 ${ }^{8}$ などへの応用例が南後恵理子氏, 上 村洋平氏, 福澤宏宣氏らによってまとめられている. 
さらに，X線光学系を用いると，XFELを極小サイズに 集光し, X線の強度を飛躍的に高めることができる。こ の超高強度 $\mathrm{X}$ 線によって, 従来は不可能であった, X線 強度に対する物質の非線形な応答を顕在化させることが 可能になる. 例えば, よく知られた X線の光電効果の過程 では, 原子がX線光子を吸収し内殼 (主に $\mathrm{K}$ 殼)の電子を 放出するが，オージェ過程若しくは蛍光過程によって，ア 卜秒からフェムト秒のオーダーでL殼の電子が遷移し, K殼の空孔は再び埋められる。しかし, 系が緩和する前に 次の $\mathrm{X}$ 線光子がくると, $\mathrm{K}$ 殼に空孔をもった原子 (中空原 子： hollow atom）と相互作用することになり，通常とは まったく異なる振る舞いを示す，従来光源ではこのよう な状態の確率は無視できるほど小さかったが, XFELを 用いると, 中空原子が多数を占める状態を生成すること さえ可能となる.9 (10) 1960 年代のレーザーの出現によっ て非線形光学の研究が一気に花開いたように, XFELに よって「非線形X線光学」が目覚ましい発展をとげよう としている. 詳しくは米田仁紀氏の記事を参照されたい.

\section{XFELの歴史}

\section{1 摇籃期から超大型施設へ}

次に, XFELの歴史を簡単にひも解きたい. 自由電子 レーザー（FEL）は, スタンフォード大学の博士課程の 学生であったJohn Madeyによって 1960 年代末に着想さ

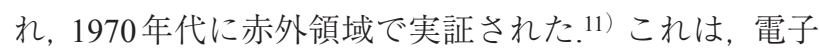
を高速に加速する加速器と, 電子を磁場で蛇行させるア ンジュレータを組み合わせたものである. 最大の特徴は, 光増幅をするための非線形媒体として, 従来のレーザー と異なり原子に束縛されていない「自由な」電子を用い ており,レーザーの波長と電子ビームエネルギーの間に 単純なスケーリング則が成り立つ, すなわちビームエネ ルギーを上げていくことで短波長化が可能，という点に ある。しかしながら，ここで開発されたFEL装置には， 光をアンジュレータ内で多数回往復させるための光共 振器が用いられており, 紫外線より短い波長領域で動作 させるのは実際には困難であった. 1980年代に, 光共振 器を使う代わりに, 長尺のアンジュレータを用いた「自 己増幅自発放射 (Self Amplified Spontaneous Emission : SASE) 型」のFELが, イタリアとロシアのグループに よって提案された. ${ }^{12), 13)} 1990$ 年代には, 高エネルギー加 速器技術の進歩, 特に電子銃の低エミッタンス化が進 み, 短波長領域でFELを実現する可能性が見えてきた。 1992 年には, UCLAのClaudio Pellegriniが, 波長 $1 \AA$ の SASE-XFELを提案した。 これは, スタンフォード線形加 速器センター (現SLAC加速器研究所) において 1960年 代に建設された2マイル線形加速器が生成する, 加速工 ネルギー $50 \mathrm{GeV}$ の電子ビームを使って硬X線FELを実 現するというものであり, 後のLCLS 計画へと発展して
いった. LCLSは, 2マイル線形加速器の一部を用いた, ビームエネルギー $14 \mathrm{GeV}$ の XFEL施設として, 2000年 代に整備が開始された。 2009年4月に, 世界で初めて波 長 $1.5 \AA$ の硬X線FELの発振に成功した. ${ }^{14)}$

一方，ドイツでは，1990年代に，高繰り返しの超伝導 加速器を利用したリニアコライダー計画（TESLA 計画） の策定が進められた。当時の欧州の高エネルギー物理学 研究の拠点であったドイツ電子シンクロトロン (DESY) に, 超伝導加速器システムの R\&DのためにTESLA Test Facility（TTF）が建設されたが, そこにアンジュレータ を付加することにより, SASE-FELの試験も並行して進 められた。 2000 年には当時の世界最短波長 $(109 \mathrm{~nm})$ の 深紫外FELの運転に成功した. 15) その後も TTFは増強を 重ね，2005年に極端紫外 (Extreme Ultraviolet：EUV) 領 域のFELのユーザー施設FLASH として衣替えし, 現在 に至っている。 また, TESLA 計画の一部には, 超伝導加 速器ベースのXFEL施設の建設が含まれていたが, これ は欧州のプロジェクト European XFEL 計画へと発展し, 2009年に建設が開始された. European XFELは, DESY キャンパスからハンブルク郊外にかけて全長 $3 \mathrm{~km}$ 以上 のトンネルを掘り, $17.5 \mathrm{GeV}$ の超伝導加速器を収容す るというきわめて大がかりな施設である. 2016年に建 設が完了し, 機器の立ち上げが進められている。ちなみ に, TESLA 計画の本体であるリニアコライダー計画は, 2004 年に, 国際プロジェクト International Linear Collider (ILC) 計画に統合され, 現在も検討が続けられている.

\section{2 コンパクトXFELの提案と SACLAの登場}

前節でみたように，XFEL計画は，もともと米国・欧州 の超大型の高エネルギー加速器プロジェクトを母体とし て始まった。したがって, きわめて大規模な施設と, そ れを建設・運用する多大なコストが前提とされていた。 しかしながら, 単一の目標を追求する高エネルギー加速 器と異なり, XFEL光源は, 多様性を身上とする光科学 のニーズに応え続けるためのツールであり，世界に1つ か2つしか施設がないという状況では, 飛躍的な発展は 難しい. この問題を解決するには, 装置のコンパクト化 を推進し, 建設・運用コストを低減させることがきわめ て重要である.さらに, コンパクト化によって, 光源の 安定性や制御性も格段に向上することが期待される。

このような背景のもと, 理研播磨において, 2000年代初 頭より，コンパクトXFELの実現可能性の検討が始まっ た. 特に重要なパラメー夕は, 電子ビームのエネルギーで ある.FELの波長はビームエネルギーの2乗に反比例する ため, 短波長化のためには電子ビームのエネルギーを高 くするというのが従来の常識であり, 結果として長大な 加速器を必要としていた。一方で, FELの波長はアンジュ レータの周期長にも比例する。したがって, 短周期長の アンジュレータが実現できれば，ビームエネルギーを抑 


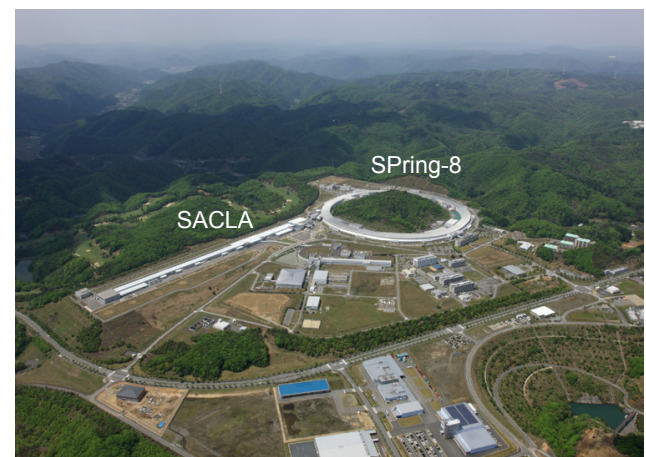

図1 SACLA と SPring-8. (SACLA and SPring-8.)

制しながら短波長FELを生成することが可能になる。

このためのキーテクノロジーとして, 真空封止型アン ジュレータの利用が提案された。 この日本発の技術は, 従来とは異なり磁石列をすべて超高真空内に配置する ことで, 対向する磁極間の間隙をぎりぎりまで狭くし, 短周期長でも十分な摇動磁場を与えるというものであ る.1990年代に建設されたSPring-8の蓄積リングに本格 的に導入され, 放射光向けのデバイスとしては十二分な 実績を積んでいた，これに, 高加速勾配のCバンド加速

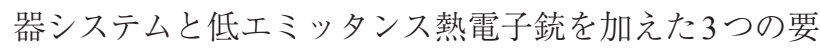
素技術の開発が, 2001 年に開始された。ささらに, これら を組み合わせたコンパクトXFELシステムの実証機と して, ビームエネルギー $250 \mathrm{MeV}$ の SCSS 試験加速器の 建設が2004年から進められ，2006年には波長 $49 \mathrm{~nm}$ の EUV-FEL の生成に成功した. ${ }^{16), 17)}$

このような技術革新を基盤に, 2006年, XFEL施設 SACLAの建設が開始された. 2011 年3月には, 当初の計 画どおり建設を完了(図1), 同年4月より精密調整を開始 し, 6月には当時の世界最短波長の $1.2 \AA$ で硬X線FELの 生成に成功した. 2012 年 3 月から利用運転を行っている.

このSACLAの成功は, 超大型の規模でなくても XFEL 施設が建設・運用できるということを証明したことにほ かならず，世界各国を大いに刺激した，特に，スイス。 ポールシェラー研究所 (PSI) と韓国・ポハン加速器研究 所（PAL）は, SACLAに類似したコンパクトXFEL施設 の建設を開始し，2016年には，それぞれ EUV 領域，硬X 線領域における FEL生成に成功した. European XFEL と ともに, 2017年より利用運転が開始される予定である.

\section{SACLAのユニークさ}

前章でみてきたように，XFELはまだ歴史が浅い光源であ り,さまざまな最新テクノロジーの投入が継続して行われて いる. 特に, SACLAは, 世界初のコンパクトFELとして構想 されたこともあって, 他施設とは明確に異なるいくつかの特 徵を有している.ここでは, その一端を紹介したい.

XFEL加速器は, 入射部, 主加速器部, アンジュレー

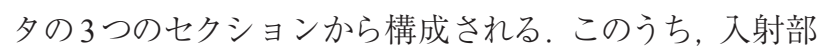

は, 電子ビームの素性を支配するためきわめて重要であ る. SACLAの入射部には, 他施設で一般的な RFフォト カソード電子銃とは異なり, 熱電子銃と多段バンチ圧縮 システムの組み合わせが採用されている. 結果として, 電子バンチの中で限られた時間領域にXFELパルスの発 振が集中するようになり，10 フェムト秒以下という超短 パルス幅で, $50 \mathrm{GW}$ 以上という高いピークパワーを常時 供給することが可能となった。 これに対して, LCLSで は，1パルス当たりのフォトン数はSACLAより多いが, パルス幅も数十フェムト秒と長いため, ピークパワーに 換算するとSACLAのほうが上回っている. Diffractionbefore-destruction法や, 非線形X線光学など,「切れのい い」超短パルスを必要とする実験には有利である。

また,アンジュレータに関して, LCLS PFLASHでは, 磁極間のギャップが固定されたデバイスが用いられてお り, 波長を変更するにはビームエネルギーを変える必要 がある、一方で, SACLAの真空封止アンジュレータは, 磁極間のギャップを可変にすることによって, ビームエ ネルギーを固定したまま, 広い範囲にわたって波長を迅 速に走査することが可能である. また, 全長 $5 \mathrm{~m}$ のアン ジュレータが総数で約 20 台用いられているが, 上流セク ションと下流セクションのギャップ值を異なる值に設 定することにより2色のXFELが生成でき, さらにセク ション間のシケインを利用することにより2色のパルス の時間間隔を最大数 100 フェムト秒まで, サブフェムト 秒の精度で制御することが可能である.18)この 2 色 XFEL パルスは, X線ポンプ・X線プローブによる超高速ダイ ナミクスの探査 ${ }^{19)}$ や, 非線形X線光学の実験 ${ }^{10)}$ に押い て強力なツールとなっている.

また,わが国は, X線オプティクスの研究開発におい て，半世紀にわたって優れた成果を上げてきた，XFEL

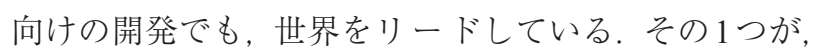
集光ミラーの開発である. 今世紀に入って, 大阪大学の 山内和人教授のグループは, Elastic Emission Machining （EEM）による超精密加工技術に基づくX線集光ミラー を開発し, SPring-8において $7 \mathrm{~nm}$ という極小ビームサイ ズを実現した，この技術がSACLAにも活用され，ビー ムサイズを $50 \mathrm{~nm}$ まで絞ることにより, 世界最高のX線 強度 $10^{20} \mathrm{~W} / \mathrm{cm}^{2}$ を達成した. ${ }^{20)} こ の$ 超高強度 $\mathrm{X}$ 線を用い て銅原子を励起することにより, 世界初の硬X線原子 レーザーが実現された. ${ }^{10)}$ また, XFELのスペクトルを 高分解能かつシングルショットで計測するために, 高 精度ミラーと結晶分光素子を組み合わせた $\mathrm{X}$ 線スペク トロメータが開発され, ${ }^{21)}$ XFEL パルス幅の推定 ${ }^{22}$ や, dispersive型のXFEL吸収分光法 ${ }^{23)}$ に応用された。ささら に, XFELのパルスを光学系で2つに分割し, ディレイ をつけて再結合する, split-and-delay光学系の開発 ${ }^{24)}$ が, 世界に先駆けて進められている。 
XFELのパルス性を活かすには, シングルショットで 計測することが必須となり，多チャンネルの信号を同 時に測る二次元検出器の役割がきわめて重要となる. SACLAでは, CCD技術に基づいた高速の二次元検出器 (Multiport CCD : MPCCD検出器) 25 ) 開発し, 多くの利 用実験に安定的に適用している.ささらに, 検出器, デー 夕取得システム, 試料チャンバーなどの各コンポーネン 卜を一体化したシステムを構築し，高度な利用を実現し ている. ビームラインや利用システムの詳しい情報は, 本号の登野健介氏の記事を参照されたい.

\section{5. 今後の展望}

3 章で述べたように, 2017年以降, XFEL施設は日米の 二極から，欧州・アジア勢も加えた多極へと拡大してい く.このような状況の中で, SACLAは, 国際的なプレゼ ンスを維持しながら, サイエンス・イノベーションのさ らなる活性化に貢献することが求められる，前章で紹介 したような特徵を一層先鋭化させると同時に, XFELを もっと使いたいという利用者からの旺盛な要求に応える ため, SACLAでは, 利用機会の拡大を図ってきた. 2014 年には, 2本目の硬X線FEL ビームラインとしてBL2を 建設した. 2017年からは, SACLA加速器からの電子ビー ムをパルスごとに振り分けることにより,26) 既存のBL3 との並行利用を開始する予定である。また，軟X線FEL 専用加速器として, SCSS 試験加速器をSACLAアンジュ レータホールに移設し，2016年より利用を開始した。

また, SACLAは産業イノベーションへの貢献も期待さ れている。これまでみてきたように，XFELを利用するに は新たな手法や装置を用いる必要があり, 供用当初は, 非専門家や企業が主体となった利用は容易ではなかっ た。この状況を改善するために, 2014年度より, SACLA では「SACLA産学連携プログラム」(2016年より「SACLA 産業利用プログラム」に改称 $\left.{ }^{27)}\right)$ を実施してきた。これ は, 企業, XFEL利用に習熟した利用者 (主に大学・研究 機関 ), SACLA施設の3者が協力して, 産業利用振興に 必要な調査研究を行うものである。これまでの取り組み によって, 産業界の利用が着実に拡大し, 2016年度には 成果専有利用も開始された，特に, XFELのコヒーレント な超短パルスを使うことで干渉計測などのX線精密計測 が容易となり，さまざまな応用につながると期待される。

最後に，世界の潮流に目をむけたい，LCLSでは，既 存の施設に加えて, $4 \mathrm{GeV}$ の超伝導線形加速器を配備し 高繰り返し $(\sim 1 \mathrm{MHz})$ の軟X線FELを実現する「LCLSII」の建設を開始した. 2020 年を目処に利用が開始され る予定である。ささらに, 超伝導加速器を $8 \mathrm{GeV}$ まで増強 し硬X線領域まで拡大する「LCLS-II-HE」計画も検討 されている。これらは, きわめて高い平均輝度が期待
されるが, 光学系や試料への熱負荷を考えると, シン グルパルス当たりの光量を落とさざるを得ない. また, 巨額の建設・運用コストも要する。一方で, SPring-8, ESRF，APS どの第3 世代放射光源は, 「回折限界放射 光源 (Diffraction Limited Synchrotron Radiation：DLSR)」 へのアップグレードを計画して㧍り, サイエンスケース でも重複する部分が増えてくる.両者の特徵を理解しな がら, 適切に使い分けていくことが重要となろう.さら に将来の大きな目標として, 蓄積リングベースのCWXFEL光源の実現に向けた議論が世界各所で始まってい る.テクノロジーの進化の大きな流れをしっかりととら えながら, サイエンスを創っていくことが求められる.

\section{文 献}

1) T. Ishikawa, et al:: Nat. Photonics 6, 540 (2012).

2) M. Yabashi, H. Tanaka and T. Ishikawa: J. Synchrotron Rad. 22, 477 (2015).

3) R. Neutze, R. Wouts, D. van der Spoel, E. Weckert and J. Hajdu: Nature 406, 752 (2000).

4) K. J. Gaffney and H. N. Chapman: Science 316, 1444 (2007).

5) M. Suga, et al.: Nature 517, 99 (2015).

6) T. Kimura, et al:: Nat. Commun. 5, doi:10.1038/ncomms4052 (2014).

7) E. Nango, et al.: Science 354, 6319 (2016).

8) Y. Uemura, et al.: Angew. Chem., Int. Ed. 55, 1364 (2016).

9) H. Yoneda, et al:: Nat. Commun. 5, 5080 (2014).

10) H. Yoneda, et al.: Nature 524, 446 (2015).

11) L. R. Elias, et al.: Phys. Rev. Lett. 36, 717 (1976).

12) A. M. Kondratenko and E. L. Saldin: Part. Accel. 10, 207 (1980).

13) R. Bonifacio, C. Pellegrini and L. M. Narducci: Opt. Commun. 50, 373 (1984).

14) P. Emma, et al:: Nat. Photonics 4, 641 (2010).

15) J. Andruszkow, et al.: Phys. Rev. Lett. 85, 3825 (2000).

16) T. Shintake, et al.: Nat. Photonics 2, 555 (2008).

17) M. Yabashi, et al.: J. Phys. B 46, 164001 (2013).

18) T. Hara, et al.: Nat. Commun. 4, 2919 (2013).

19) I. Inoue, et al.: Proc. Natl. Acad. Sci. USA 113, 1492 (2016).

20) H. Mimura, et al.: Nat. Commun. 5, 3539 (2014).

21) M. Yabashi, et al.: Phys. Rev. Lett. 97, 084802 (2006).

22) Y. Inubushi, et al.: Phys. Rev. Lett. 109, 144801 (2012).

23) T. Katayama: Appl. Phys. Lett. 103, 131105 (2013).

24) T. Osaka, et al.: Opt. Express, 24, 9187 (2016).

25) T. Kameshima, et al.: Rev. Sci. Instrum. 85, 033110 (2014).

26) T. Hara, et al.: Rev. Sci. Instrum. 85, 033110 (2014).

27) http://xfel.riken.jp/topics/20160328.html

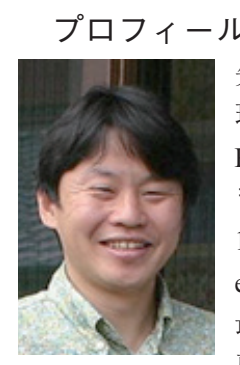

矢橋牧名 Makina YABASHI 理化学研究所放射光科学総合研究センター RIKEN SPring-8 Center T 679-5148 兵庫県佐用郡佐用町光都 1-1-1 1-1-1 Kouto, Sayo, Hyogo 676-5148, Japan e-mail: yabashi@spring8.or.jp 最終学歴：博士 (工学) 専門分野 : X線光学 現在の研究テーマ:X線光学 趣味：ピアノの練習 